\title{
Social representations of adolescents on quality of life: structurally-based study
}

\author{
Ramon Missias Moreira ${ }^{1}$ \\ Eduardo Nagib Boery ${ }^{1}$ \\ Denize Cristina de Oliveira ${ }^{2}$ \\ Zenilda Nogueira Sales ${ }^{3}$ \\ Rita Narriman Silva de Oliveira Boery ${ }^{1}$ \\ Jules Ramon Brito Teixeira ${ }^{1}$ \\ Ícaro José Santos Ribeiro ${ }^{4}$ \\ Fernanda Carneiro Mussi ${ }^{5}$
}

\footnotetext{
${ }^{1}$ Programa de Pós-

Graduação em Enfermagem

e Saúde, Universidade

Estadual do Sudoeste da

Bahia. Av. José Moreira

Sobrinho s/n, Jequiezinho.

45200-000 Jequié BA

Brasil.

ramonefisica@hotmail.com

${ }^{2}$ Faculdade de Enfermagem,

Universidade Estadual do

Rio de Janeiro.

${ }^{3}$ Departamento de Saúde, Universidade Estadual do

Sudoeste da Bahia.

${ }^{4}$ Centro de Pesquisa

Gonçalo Muniz - BA,

Fiocruz.

${ }^{5}$ Programa de Pós-

Graduação em Enfermagem

Universidade Federal da

Bahia.
}

\begin{abstract}
This study sought to conduct a comparatively analysis and describe the contents of the structure of the social representations of adolescents on quality of life. It involves descriptive, quantitative research, with the benchmark of a structural approach to social representations. The informants included 316 adolescents from three public schools in Jequie in the State of Bahia. The Spontaneous Word-Choice Eliciting Technique using the key expression "Quality of Life" was used for data collection. The responses were processed using Evoc 2003 software, which generated the Four-House Chart. The results reveal the core nucleus of the terms: healthy eating; physical activity; money; and sex. In the 1st outer circle, the words absence of disease, condoms, liberty, marijuana, housing, work and living well are featured. In the 2nd outer circle, there appeared the words difficulty, family, peace and power, and the contrasting elements of well-being and soccer. The overall consensus is that adolescents associate quality of life with sports and other healthy behavior activities, and are influenced by the desires and curiosities of adolescence.
\end{abstract}

Key words Social perception, Adolescent, Quality of life 


\section{Introduction}

The adolescence is characterized by several changes in the body, on the way of being, thinking and acting of adolescents; being marked by biological, social and behavioral changes, which significantly affect eating habits, social relations, family, cultural and spiritual, and, in a sense, of (dis) agreement with your own self'.

It is a process of acquiring healthy lifestyle behaviors and also exposure to various risk situations may arise where serious consequences for your future and that may adversely affect their quality of life. ${ }^{2}$ This perspective, considering that the quality of living is a widely discussed nowadays due to the paucity of scientific research directed at adolescents ${ }^{3}$, theme emerged the need to conduct this study.

The quality of life permeates many areas of knowledge, and though there is not a unique concept, it is defined by The WHOQOL Group ${ }^{4}$ as the self-perception of their position in life in the context of culture and value systems in which they live and in relation to their goals, expectations, standards and concerns. It becomes thus a subjective concept and multimodal, incorporating aspects related to the various dimensions that make up the human being, such as physical, psychological, social, environmental and affective aspects.

Considering the assumptions described above, this study aimed to describing the contents and comparatively analyzing the structure of social representations of teenagers on their quality of life.

\section{Method}

This is a descriptive study of a quantitative ${ }^{6}$ approach that had as reference the Central ${ }^{7}$ Nucleus of the Theory of Social Representations ${ }^{8}$. This structural approach, or the Central Nucleus Theory, emphasizes the cognitive-structural dimension of social representations, as it is organized around a central core that determines at the same time, its significance and internal organization setting strength and support to the representation $^{7,8}$.

The study was conducted in three public schools in the municipality of Jequié - Bahia and the sample size calculation was performed using Epi Info version 3.5.3.0 software, Being given 272 informants, from a population of 1.161 adoles- cents. Therefore, we considered the addition of a sample of $20 \%$ increase due to possible sample loss, totaling 327 respondents in the sample.

Participated teenagers, aged between 13 and 19 years old, attending high school in the morning and afternoon shifts. In this study, we obtained $3.4 \%$ of sample loss $(n=11)$, due to 3 refused to participate and 8 subjects who were absent in the two search attempts, totaling 316 participants in the sample.

The survey was conducted from September 2011 to July 2012 for data collection technique was used to Evocation of Words ${ }^{7}$, from the inductive term "quality of life". Thus, the informants were asked to recall the first 5 words that come immediately to mind them, because after the inducer stimulus 9 . The data produced were processed through EVOC $^{10}$ Version 2003 software being organized according to the distribution of technical terms produced a Framework of Four Houses ${ }^{10}$, which expresses the content and structure of the central social representations of the object in question.

The Table of Four Houses corresponds to similar to a Cartesian system, composed of four separate from the values of Frequency and Evocations Average and Average of Average Summoning Orders quadrants figurative scheme. The abscissa ( $\mathrm{x}$ ) is represented by values of Average Orders averages Evocation while the vertical axis (y) consists of values of frequency of appearance of terms mentioned ${ }^{10}$.

This study originates from a Masters' Dissertation, whose project was approved by the Ethics Committee in Research of the State University of Southwest Bahia (CEP / UESB). Underage informants participated only after submission of the Statement of Informed Consent Form (ICF) signed by parents and/or guardians ${ }^{11}$.

\section{Results}

According to the characterization of participants in this study (Table 1), it was observed that the majority were female, corresponding to $56.3 \%$ of the sample. The age of puberty ranged between 13 and 19 years old, and the age group with the highest incidence was $16-17$ years old $(46,2 \%)$.

Regarding self-reported race of the participants, there was a greater number of African descent (black and brown) totaling $77,8 \%$ of the subjects. Most teenagers are enrolled in the 1st year of high school, corresponding to $55,7 \%$ of 
the participants. Still, with regard to the period of study, the majority of adolescents $(59,2 \%)$ studies in morning shift.

The synthesis of the results presented by Table 2 was developed from the analysis of the corpus formed by the evocations of 316 social subjects searched. It was noticed that in the process of applying the Technique of evocation of Words were prepared after evocations 1549 approach for semantic similarity resulted in 66 different words or phrases, showing average orders evocation equal to 3 , on a scale of 1 to 5 .

It is presented in the same frame, the total number of words that evoked was 1549, and these were discarded from the analysis because they were 672 words evoked with minimum frequency below the cutoff, which was equal to 34 , leaving 877 words. Had 66 different expressions, and analyzed 17 evocations; the average frequency of evocations was 52 .

Thus, through the segment RANGMOT of EVOC 2003, which classifies the words in lexical inflows and according to the occurrence of evocations, based on the calculation of simple and cumulative frequencies, it was possible to construct Table 3, which has evoked the 17 words more often, in order from 1 st to 5 th evocation.

Table 1. Socio-demographic characteristics of adolescents in the study "Quality of life and health of adolescents: a study of social representations". Jequié-BA, 2012.

\begin{tabular}{lrr}
\hline & \multicolumn{2}{c}{ Frequency } \\
\cline { 2 - 3 } \multicolumn{1}{c}{ Variable } & N & $\%$ \\
\hline Gender & & \\
$\quad$ Male & 138 & 43.7 \\
Female & 178 & 56.3 \\
Age & & \\
$13-15$ & 131 & 41.5 \\
$16-17$ & 146 & 46.2 \\
$18-19$ & 39 & 12.3 \\
Race & & \\
$\quad$ White & 70 & 22.2 \\
Black & 105 & 33.2 \\
Brown & 141 & 44.6 \\
Schooling & & \\
$1^{\text {st }}$ year of high school & 176 & 55.7 \\
$2^{\text {nd }}$ year of high school & 85 & 26.9 \\
$3^{\text {rd }}$ year of high school & 55 & 17.4 \\
Shift of Study & & \\
$\quad$ Afternoon & 187 & 59.2 \\
Evening & 129 & 40.8 \\
\hline
\end{tabular}

The results presented allow a statistical evaluation of data regarding the frequency (importance of contribution of the modes in the construction of the factors), and graphically represent variations in the semantic field of the spatial organization of evocations.

Established categorization, through the semantic aggregation and suppression of insignificant terms, the corpus was to complete 877 words, equivalent to $56,6 \%$ of the evoked terms. Also as seen in Table 2, the overall frequency of terms varies the 1-5 zones, decreasing from 225 to 141 .

With these data, and considering the TABRGFR report issued in processing of EVOC 2003 Table of Four Houses ${ }^{10}$ (Frame 2), which expresses the content and the structure of social representations of the phenomenon studied was prepared. To construct this framework were considered as criteria the average frequency of invocations; and the weighted frequency of the order of evocations ${ }^{12}$. The mean of the average orders recall was 3 ; the minimum frequency was presented by the value 34 , with an average frequency recorded in 52 .

For interpretation of the results there were adopted the approach proposed by $\mathrm{Abric}^{7}$ where terms that met at the same time, the criteria for recall most frequently and in the first place, ie, hierarchical order, supposedly greater importance in the cognitive schema the subject, ie if as a hypothesis would configure the core of social representation.

In Frame 2, we distinguish four important elements for the apprehension of social representations of teenagers on their quality of life. In

Table 2. Summary of results from analysis of the corpus formed by evocations of the participants in the study "Quality of life and health of adolescents: a study of social representations". Jequié- BA, 2012.

\begin{tabular}{lr}
\hline \multicolumn{2}{c}{ Technique of free evocation of words } \\
\hline \multicolumn{1}{c}{ Synthesis } & \multicolumn{1}{c}{ No } \\
\hline Number of informants & 316 \\
Total number of words evoked & 1.549 \\
Number of different words & 66 \\
Minimum frequency/Cut-off & 34 \\
Average frequency of evocations & 52 \\
Average of the average orders evocations & 3 \\
Number of evocations despised & 672 \\
Total number of analyzed evocations & 17 \\
\hline
\end{tabular}


this sense, consists of the core (upper left); by elements of the $1^{\text {st }}$ periphery (upper right quadrant) and $2^{\text {nd }}$ periphery (lower right quadrant); and by contrast elements of representation (lower left quadrant $)^{12}$.
For this study, Table 4 was analyzed descriptively, establishing the correlation of evoked terms with the Structural Approach to Social Representations, allowing the understanding of the organization of the representation ${ }^{7}$. Evoca-

Table $3.1^{\text {st }}$ to $5^{\text {th }}$ order evocation of words evoked more often, from the study "Quality of life and health of adolescents: a study of social representations”. Jequié/BA/BR, 2012.

\begin{tabular}{|c|c|c|c|c|c|c|c|}
\hline \multirow[b]{2}{*}{ Words Evoked } & \multicolumn{5}{|c|}{ Order of Evocation } & \multirow[b]{2}{*}{ Frequency of Evocation } & \multirow[b]{2}{*}{ OME } \\
\hline & $1^{\text {st }}$ & $2^{\text {nd }}$ & $3^{\text {rd }}$ & $4^{\text {th }}$ & $5^{\text {th }}$ & & \\
\hline Healthy eating & 39 & 35 & - & - & - & 74 & 1.47 \\
\hline Physical activity & 40 & 27 & - & - & 2 & 69 & 1.51 \\
\hline Money & 46 & 13 & - & - & 4 & 63 & 1.46 \\
\hline Work & 2 & 4 & 25 & 15 & 16 & 62 & 3.61 \\
\hline Home & 3 & 9 & 17 & 20 & 12 & 61 & 3.48 \\
\hline Freedom & 9 & 15 & 11 & 12 & 11 & 58 & 3.02 \\
\hline Marijuana & 1 & 1 & 41 & 12 & 3 & 58 & 3.26 \\
\hline Sex & 42 & 16 & - & - & - & 58 & 1.28 \\
\hline Absence of disease & 1 & 6 & 23 & 13 & 13 & 56 & 3.55 \\
\hline Live well & - & 10 & 12 & 19 & 15 & 56 & 3.70 \\
\hline Condom & 5 & 10 & 12 & 14 & 14 & 55 & 3.40 \\
\hline Peace & 2 & 4 & 16 & 9 & 5 & 36 & 3.31 \\
\hline Soccer & 10 & 8 & 3 & 8 & 6 & 35 & 2.77 \\
\hline Wellness & 6 & 16 & 3 & 9 & - & 34 & 2.44 \\
\hline Difficulty & 8 & 5 & 3 & 5 & 13 & 34 & 3.29 \\
\hline Family & 4 & 1 & 7 & 7 & 15 & 34 & 3.82 \\
\hline Power & 7 & 5 & 6 & 4 & 12 & 34 & 3.27 \\
\hline Total & 225 & 185 & 179 & 147 & 141 & 877 & 3.0 \\
\hline
\end{tabular}

Table 4. Frame of Four Houses expressing content and the structure of social representations of the study "Quality of life and health of adolescents: a study of social representations". Jequié/BA/BR 2012.

\begin{tabular}{|c|c|c|c|c|c|}
\hline \multicolumn{3}{|c|}{ Central core } & \multicolumn{3}{|c|}{ First periphery } \\
\hline \multirow[t]{2}{*}{ Average Frequency $\geq 52$} & \multicolumn{2}{|c|}{$\mathrm{OME}<3$} & \multirow[t]{2}{*}{ Average Frequency $\geq 52$} & \multicolumn{2}{|c|}{$\mathrm{OME} \geq 3$} \\
\hline & Freq. & OME & & Freq. & OME \\
\hline Healthy eating & 74 & 1.47 & Absence of disease & 56 & 3.55 \\
\hline Physical activity & 69 & 1.51 & Condom & 55 & 3.40 \\
\hline Money & 63 & 1.46 & Liberty & 58 & 3.02 \\
\hline \multirow[t]{4}{*}{ Sex } & 58 & 1.28 & Marijuana & 58 & 3.26 \\
\hline & & & Home & 61 & 3.48 \\
\hline & & & Work & 62 & 3.63 \\
\hline & & & Live well & 56 & 3.70 \\
\hline \multicolumn{3}{|c|}{ Contrast zone } & \multicolumn{3}{|c|}{ Second periphery } \\
\hline \multirow[t]{2}{*}{ Average Frequency $<52$} & \multicolumn{2}{|c|}{$\mathrm{OME}<3$} & \multirow[t]{2}{*}{ Average Frequency $<52$} & \multicolumn{2}{|c|}{$\mathrm{OME} \geq 3$} \\
\hline & Freq. & OME & & Freq. & OME \\
\hline Wellness & 34 & 2.44 & Difficulty & 34 & 3.29 \\
\hline \multirow[t]{3}{*}{ Soccer } & 35 & 2.77 & Family & 34 & 3.82 \\
\hline & & & Peace & 36 & 3.31 \\
\hline & & & Power & 34 & 3.27 \\
\hline
\end{tabular}


tions that appear in the upper left quadrant are those most significant for the subject, composing the core, namely: healthy eating, physical activity, money and sex. In this study, the words that made up the first peripheral system were: absence of disease, condoms, liberty, marijuana, housing, work and live well. These lexicons reinforce the core elements and are considered peripheral, flexible and tangible elements, with greater frequency and lesser importance ${ }^{10,12}$ attributed by adolescents interviewed.

Regarding the second periphery, lower right quadrant, understood the words, difficulty, family, peace and power, it was observed that these elements are more clearly peripheral, since they are less frequent and less important ${ }^{10,12}$ for teens in their representations.

Although this perspective structural approach, it was observed that the words welfare and soccer elements are less frequently and most importantly, the elements composing the contrast of the representation ${ }^{10}$ and maintaining the soundness of the core ${ }^{12}$.

\section{Discussion}

Understand the social representations of teenagers on their quality of life requires an understanding of the multiple factors which are related to their membership, noting it is not just the biological aspects of this transition period, and also their roles, values, beliefs and attitudes.

From the analysis of the structure of social representations of teenagers on quality of life was observed that to achieve such a healthy diet, which can be characterized by feeding practices with the intake of vegetables, fruits and other foods is necessary, and excluding If the fries, sandwiches, soft drinks and other foods that, in some way, can affect the process of health/disease $^{13}$.

Evocations that emerged in the structure of representation this study reinforced the findings of a study ${ }^{14}$ on social representations of 753 teenagers about health, which represented health as a way to maintain healthy lifestyle behaviors, a biomedical dimension and towards improving quality of life. In addition, there were changes of location of some elements listed, alternating between the central core and the peripheral system ${ }^{14}$.

The practice of physical activity in conjunction with a healthy diet has benefits for health effects and therefore may reduce levels of anxiety, stress and depression, improve mood, increase in physical and psychological well-being, self-esteem, income in studies and other activities of daily life, influencing positively the quality of life ${ }^{15}$.

Words wellness, live well, food, work, activity, sport and disease in the study of Reis et al. ${ }^{14}$ and suggest that the representations of teenagers on health are similar to the figurative structure of adolescent quality of life. The dimensions of lifestyle are linked to behaviors that result in a condition of health, being related to a biomedical dimension, interpreted as the absence of disease (a term evoked in this study), and considering that to have health and quality of life is necessary the adoption of a healthy lifestyle, being held here by evocations healthy eating and physical activity.

The Ministry of Health, in order to promote healthy habits, aimed at prevention of chronic diseases and the consequent improvement in the quality of life of Brazilians, among them teenagers, implemented strategies that direct attention to this public, such as the Academy of Health Program the National Survey of School Health (PENSE), the Adolescent health Program (PROSAD) and the School Health Program (PSE), which are initiatives to encourage increased physical activity, health education and care health ${ }^{16}$.

Actions like these can reduce non-communicable and chronic incidence and prevalence of diseases and communicable diseases, adulthood, since teenagers can act as multipliers of the actions of health education and from your awareness will become healthy adults.

Still in possession of the structural elements analyzed in this study, it was understood, through lexicons sex and condoms, those representations of the quality of life on membership of adolescents are associated with initiation and sexual practice. This finding is consistent with the study of Cromack et al. ${ }^{17}$, which showed that the teenager relates your health with your body in transition and the beginning of their sexual life.

This thinking is characteristic of this stage of development, is the reason the body taking on new sexual functions, the mental development by hormonal issues at puberty, the emotional relationships, and the act of challenge, curiosity, and pleasure or exacerbated by the constant feeling of omnipotence, to overcome obstacles and prove the unknown. By establishing a parallel with the study of Oliveira et al. ${ }^{18}$ with 746 adolescents from public schools in Rio de Janeiro, which evoked a total of 2.956 words associated with the term sexuality, and of these 253 were different, it was observed 
that the terms condoms and sex appear in the central core, demonstrating that sexual practice is coupled prevention.

However, for teens surveyed sex gives them quality of life, however, condom use is located in the periphery of your first thought, so often, condom use may be being overlooked, reinforcing the idea that condoms is not being used routinely in their sexual practices and thus exposing teens to various risk situations.

However, it also seized, the evocations of adolescent quality of life point to a transition between the elements of the structure of the organization of their social representations of this phenomenon, overcoming barriers of biological dimension, becoming a more updated content, multidisciplinary, multidimensional and polysemic.

This modification of representational structure and migration of peripheral elements has big stake in this transformation process of social representations, since its components are more affordable living, concrete and related to the immediate reality of the subject, therefore, are susceptible to exchange with social dynamics, showing how the practices of health education affects these representations, modifying the perception and risk behavior of adolescents ${ }^{7}$.

Gains great notoriety evocation of word marijuana, this study represented the first periphery. This is a potentially stimulant ${ }^{19}$ drug and adolescence comprises a period of challenges, discoveries, social integration and self-assertion of power and popularity among peers. In the design of teens, marijuana use deceptively would supply their wants and desires, making them invulnerable to any risks and suffering, protecting them against danger, which according to Lionel and Abric $^{19}$ constitutes a public health problem in the international arena. In another study ${ }^{20}$ conducted with French students, there was wide use of this drug by adolescents, which impacts negatively on the quality of life for us.

Thus, teenagers see in this illicit drug consumption a chance to escape reality and conflicts, internal and external, who experience such as early sexual experimentation, impulsivity, antisocial behavior sometimes, low self-esteem, conflict intrafamily, the search for independence and identity, freedom of expression, the tendency to indiscipline, disorganized, the search for adventure, among other ${ }^{19,20}$.

By observing the representational structure of adolescents, it is understood that the desire for financial independence and the longing for freedom and go-come-to-satisfy your personal needs, as the owners own reason and the decision was expressed by the term money in the central core, and reinforced by evocations freedom and work in the first periphery, having been raised in the second periphery family.

The representation of work associated with quality of life can be explained for being the way they have to acquire their independence, and therefore have their own financially and even your family's livelihood, plus the feeling of freedom and autonomy that money can offer you, and the sense of power that can give it, assigning these teen social status and representation in family environment and social group which is inserted ${ }^{21}$.

Therefore, the elements of seized contrast, have close links with the elements of the core, as football is considered a form of physical activity, or a chance to work predilection of most young people and that physical activity, combined with healthy diet and have sufficient financial resources to maintain their needs, you can ensure your physical and mental well-being, positively influencing the quality of life.

The evocation welfare, which also appears as an important element of contrast becomes a cognitive component known as the perception of life satisfaction, in that sense, this study considers the welfare as an area of research that attempts to grasp evaluations that people make about their lives $^{22}$.

Regarding the second periphery, here constituted by the lexicons, difficulty, family, peace and power, it was understood that teens crave for changes in their habits and lifestyles to improve their quality of life, however, note that it is an individual desire, characteristic of the adolescent stage, where the family is located on the far periphery of their social representation, according with the study by Oliveira et al. ${ }^{23}$. Comparatively, this study with teens from Jequié, Bahia; these participants also established a dichotomy in their thinking, and sometimes positive, neutral and negative dimensions, balancing thus far these peripheral elements.

In this sense, while the term refers to the difficulty experienced social aspects (such as unemployment, lack of financial resources, etc.), there is a need, as in the study by Oliveira et al. ${ }^{23}$, his identification with the adult by term power (giving it representation), and family support to meet the needs of these adolescents and able to provide you with peace and improving the quality of life. 
That said, one notes the importance attached by them to the difficulty to acquire healthy habits and having money, as well as the peace and sense of power that these elements can bring to your life and the importance of sex and family have in promoting ${ }^{24}$ sexual health and concreteness of their quality of life ${ }^{25}$. Despite the function of protecting the core and are more readily associated with the immediate context of these social actors, and can be configured as the true periphery of these representations.

\section{Conclusion}

It is perceived that adolescents associate the quality of life to sports and other healthy lifestyle habits, being influenced by the desires, curiosities and pleasures of adolescence, like sex, football, the use of marijuana. They also report difficulty conquering able to provide them with welfare, however, see at work a way to provide the resources needed to live well and in peace with his family means, besides giving them representation in the social environment in which are inserted.

Therefore, it is believed that from a psychosocial analysis of individuals in relation to the object of study can contribute to the reflection and the direction of the actions and strategies that culminate in interventions for disease prevention, promotion and maintenance of quality of life adolescents, in addition to supporting the adolescents themselves, managers and teams formulators of public policies on health and education.

\section{Collaborations}

RM Moreira, IJS Ribeiro, RNSO Boery, EN Boery, DC Oliveira, ZN Sales, JRB Teixeira e FC Mussi participated equally in all stages of preparation of the article. 


\section{References}

1. Camelo LV, Rodrigues JFC, Giatti L, Barreto SM. Lazer sedentário e consumo de alimentos entre adolescentes brasileiros: Pesquisa Nacional de Saúde do Escolar (PeNSE), 2009. Cad Saude Publica 2012; 28(11):21552162.

2. Andrade SSCA, Yokota RTC, Sá NNB, Silva MMA, Araújo WN, Mascarenhas MDM, Malta DC. Association between physical violence, consumption of alcohol and other drugs, and bullying among Brazilian adolescents. Cad Saude Publica 2012; 28(11):1725-1736.

3. Dantas RAS, Sawada NO, Malerbo MB. Pesquisa sobre qualidade de vida: revisão da produção científica das universidades públicas de São Paulo. Rev Latino-am Enfermagem 2003; 11(4):532-538.

4. The Whoqol Group. The World Health Organization quality of life assessment (WHOQOL): development and general psychometric properties. Soc Sci Med 1998; 46(12):1569-1585.

5. Chavez L, Mir K, Canino G. Starting from scratch: the development of the adolescent quality of life- mental health scale (AQOL-MHS). Cult Med Psychiatry 2012; 36(3):3465-3474

6. Minayo MCS, Deslandes SF, Gomes R. Pesquisa social: teoria, método e criatividade. 32a ed. Petrópolis: Vozes; 2012.

7. Abric JC. A abordagem estrutural das Representações Sociais. In: Moreira ASP, Oliveira DC, organizadores. Estudos interdisciplinares de representações sociais. $2^{\mathrm{a}} \mathrm{ed}$. Goiânia: AB; 2000.

8. Moscovici S. Representações sociais: investigações em psicologia social. 9a ed. Petrópolis: Vozes; 2012.

9. Gomes AMT, Oliveira DC, Sá CP. Social representations of the Brazilian national health care system in the city of Rio de Janeiro, Brazil, according to the structural approach. Rev Latino-Am Enfermagem 2008; 16(1):122-129.

10. Vergès P. Ensemble de programmes permettant l'analyse des evocations: manuel versoin 5 . Aix-en-Provence: Laboratoire Méditerranée en Sociologie; 2002.

11. Lima RAG. Direitos da criança e do adolescente: desafios atuais. Rev Latino-am Enfermagem 2012; 20(3):[2 telas].

12. Oliveira DC, Marques SC, Gomes AMT, Teixeira MCTV. Análise das evocações livres: uma técnica de análise estrutural das representações sociais. In: Moreira ASP, Camargo BV, Jesuíno JC, Nóbrega SM. Perspectivas teórico-metodológicas em representações sociais. João Pessoa: Editora UFPB; 2005. p. 573-603.

13. Costa LCF, Vasconcelos FAG, Corso ACT. Factors associated with adequate fruit and vegetable intake by schoolchildren in Santa Catarina State, Brazil. Cad Saude Publica 2012; 28(6):1133-1142.
14. Reis AT, Oliveira DC, Gomes AMT. Social Representations about health among adolescents at public schools in the municipality of Rio de Janeiro. Rev Enferm UERJ 2009; 17(4):473-478.

15. Hallal PC, Victoria CG, Azevedo MR, Wells JC. Adolescent physical activity and health: a systematic review. Sports Med 2006; 36(12):1019-1030.

16. Bloch KV, Kuschnir MC, Szklo M. Cardiovascular risck in adolescence. Cad Saude Publica 2012; 28(7):12201221.

17. Cromack LMF, Bursztyn I, Tura LFR. The look of teenagers about health: a study on social representation. Cien Saude Colet 2009; 14(2):627-634.

18. Oliveira DC, Gomes AMT, Pontes APM, Salgado LPP. Attitudes, feelings and images on the social representation of sexuality among adolescents. Esc Anna Nery Rev Enferm 2009; 13(4):817-823.

19. Lionel D, Abric J-C. Distance à l'objet et représentations du cannabis. Revue internationale de psychologie sociale 2007; 20(3):77-104.

20. Peretti-Watel P. Neutralization theory and the denial of risk: some evidence from cannabis use among french adolescent. Br J Sociol 2003; 54(3):21-42.

21. Oliveira BRG, Robazzi MLCC. O trabalho na vida dos adolescentes: alguns fatores determinantes para o trabalho precoce. Rev Latino-am Enfermagem 2001; 9(3):83-89.

22. Souza LDM, Psychological well-being of young people 18 to 24 years of age and associated factors. Cad Saude Publica 2012; 28(6):1167-1174.

23. Oliveira DC, Fischer FM, Teixeira MCTV, Sá CP. A positividade e a negatividade do trabalho nas Representações Sociais de adolescentes. Psicol Reflex Crit 2005; 18(1):125-133.

24. Borges ALV, Nichiata LYI, Schor N. Conversando sobre sexo: a rede sociofamiliar como base de promoção da saúde sexual e reprodutiva de adolescentes. Rev Latino -am Enfermagem 2006; 14(3):422-427.

25. Silveira MF, Almeida JC, Freire RS, Ferreira RC, Martins AEBL, Marcopito LF. Qualidade de vida entre adolescentes: estudo seccional empregando o SF-12. Cien Saude Colet 2013; 18(7):2007-2015

Article submitted 22/08/2013

Approved 15/10/2013

Final version submitted 22/10/2013 